\title{
Agmatine deiminase pathway genes in Lactobacillus brevis are linked to the tyrosine decarboxylation operon in a putative acid resistance locus
}

\section{Correspondence \\ Patrick M. Lucas \\ patrick.lucas@oenologie. \\ u-bordeaux2.fr}

Received 23 January 2007

Revised 2 March 2007

Accepted 8 March 2007

\author{
Patrick M. Lucas, ${ }^{1}$ Victor S. Blancato, ${ }^{2} \dagger$ Olivier Claisse, ${ }^{1}$ Christian Magni, ${ }^{2} \dagger$ \\ Juke S. Lolkema ${ }^{2}$ and Aline Lonvaud-Funel ${ }^{1}$ \\ ${ }^{1}$ UMR 1219, Université Bordeaux 2, INRA, ISVV, Talence, France \\ ${ }^{2}$ Molecular Microbiology, Groningen Biomolecular Sciences and Biotechnology Institute, University \\ of Groningen, Haren, The Netherlands
}

\begin{abstract}
In lactic acid bacteria ( $\mathrm{LAB}$ ), amino acids and their derivatives may be converted into aminecontaining compounds designated biogenic amines, in pathways providing metabolic energy and/ or acid resistance to the bacteria. In a previous study, a pathway converting tyrosine to tyramine was detected in Lactobacillus brevis and a fragment of a gene possibly involved in the production of another biogenic amine, putrescine, from agmatine, was detected in the same locus. The present study was carried out to determine if $L b$. brevis actually harbours two biogenic amineproducing pathways in the same locus and to investigate the occurrence of the two gene clusters in other bacteria. Sequencing of the DNA locus in $L b$. brevis revealed a cluster of six genes that are related to previously reported genes of agmatine deiminase pathways but with marked differences such as two genes encoding putative agmatine deiminases rather than one. Heterologous expression of encoded enzymes confirmed the presence of at least one active agmatine deiminase and one amino acid transporter that efficiently exchanged agmatine and putrescine. It was concluded that the $L b$. brevis gene cluster encodes a functional and highly specific agmatine deiminase pathway. Screening of a collection of 197 LAB disclosed the same genes in 36 strains from six different species, and almost all the positive bacteria also contained the tyrosine catabolic pathway genes in the same locus. These results support the hypothesis that the agmatine deiminase and tyrosine catabolic pathways belong to a genomic region that provides acid resistance and that is exchanged horizontally as a whole between LAB.
\end{abstract}

\section{INTRODUCTION}

Lactic acid bacteria (LAB) can produce metabolic energy or increase their acid resistance by using catabolic pathways that convert amino acids or their derivatives into aminecontaining compounds designated biogenic amines (Molenaar et al., 1993; Fernández \& Zúñiga, 2006). In bacteria, biogenic amines may serve physiological functions

tPresent address: Instituto de Biología Molecular y Celular de Rosario (IBR-CONICET) and Departamento de Microbiología, Facultad de Ciencias Bioquímicas y Farmacéuticas, Universidad Nacional de Rosario, Suipacha 531 (S2002LRK), Rosario, Argentina.

Abbreviations: AgDI, agmatine deiminase; AgmP, agmatine permease; $L A B$, lactic acid bacteria; TDC, tyrosine decarboxylation.

The GenBank/EMBL/DDBJ accession number for the sequence determined in this work is AF446085.

A supplementary table showing the distribution of AgDI and TDC gene clusters in $L A B$ is available with the online version of this paper. such as cell proliferation control, but they are more generally released into the medium as the end products of the catabolic pathways (Tabor \& Tabor, 1985; Griswold et al., 2006). In fact, excretion of the amine is an essential step in the pathways (see below). LAB carrying amino acid catabolic pathways are an important source of biogenic amines in foods (Ten Brink et al., 1990; Stratton et al., 1991; Silla Santos, 1996). There is interest in avoiding the proliferation of these bacteria because ingestion of foods containing large quantities of biogenic amines may cause human health issues such as headache, palpitations, flushing or vomiting (Silla Santos, 1996). Recently the genes of diverse pathways producing biogenic amines were identified in LAB (for a review, see Fernández \& Zúñiga, 2006). Interestingly, the pathways are strain specific rather than species specific, suggesting that horizontal gene transfer may account for their dissemination in LAB (Lucas et al., 2005; Marcobal et al., 2006). 
There are two types of amino acid catabolic pathways that lead to biogenic amine formation. The decarboxylation pathways involve only two proteins, a decarboxylase and a transporter protein. The former converts the amino acid in the cytoplasm into the biogenic amine and carbon dioxide; the latter is responsible for the uptake of the amino acid from the medium and the excretion of the amine in an exchange process. The pathway generates proton-motive force and alkalinizes the cytoplasm (Lolkema et al., 1996; Sobczak \& Lolkema, 2005). Decarboxylation pathways have been described for several amino acid/biogenic amine couples such as tyrosine/tyramine and histidine/histamine (Cotter \& Hill, 2003; Fernández \& Zúñiga, 2006). The arginine deiminase pathway is the other type. Arginine is converted to ornithine. A very similar pathway has been described for agmatine, the decarboxylation product of arginine, which yields putrescine (Driessen et al., 1988; Griswold et al., 2004; Llácer et al., 2006). The pathway consists of one transport step and the sequential activities of three enzymes (for a review, see Fernández \& Zúñiga, 2006). As in the decarboxylation pathways, the transporter is responsible for the combined uptake and excretion of substrate and product, respectively, i.e. arginine/ornithine and agmatine/putrescine exchange. The first enzyme, arginine/agmatine deiminase, deiminates the substrate, yielding citrulline/carbamoylputrescine and ammonia. Next, the intermediate is phosphorylated from $\mathrm{P}_{\mathrm{i}}$ by an ornithine/putrescine transcarbamylase, yielding carbamoylphosphate and the end product ornithine/putrescine. In both pathways the final reaction is carried out by a carbamate kinase producing ATP, $\mathrm{CO}_{2}$ and $\mathrm{NH}_{3}$ from carbamoyl phosphate. Therefore, the deiminase pathway generates metabolic energy in the form of ATP and produces ammonia, allowing the control of the cytoplasmic $\mathrm{pH}$.

Very few LAB producing putrescine by the agmatine deiminase (AgDI) pathway have been detected to date. These are Streptococcus mutans (Griswold et al., 2004), Enterococcus faecalis (Driessen et al., 1988; Llácer et al., 2006) and Lactobacillus hilgardii (Alberto et al., 2007). In S. mutans and Ent. faecalis, the pathway was linked to an operon of four genes encoding an AgDI, a putrescine transcarbamylase, a carbamate kinase and an amino acid transporter (Griswold et al., 2004; Llácer et al., 2006). The specificity of the latter was not examined, but was proposed to be the agmatine/putrescine exchanger. Transcription of the operon is under the control of the AguR regulator, which is encoded by the $a g u R$ gene located upstream of the operon (Griswold et al., 2006). Clusters of similar genes were found in the genomes of strains of Lactococcus lactis, Listeria monocytogenes, Lactobacillus sakei and Pediococcus pentosaceus (see Fig. 1; Naumoff et al., 2004a, b).

Recently, the genes and the gene products of a tyrosine decarboxylation (TDC) pathway producing the biogenic amine tyramine were identified and characterized in Lactobacillus brevis IOEB 9809 (Lucas \& Lonvaud-Funel, 2002; Lucas et al., 2003; Wolken et al., 2006). During that work a gene fragment located immediately downstream of

Lactobacillus brevis IOEB 9809 (AF446085)
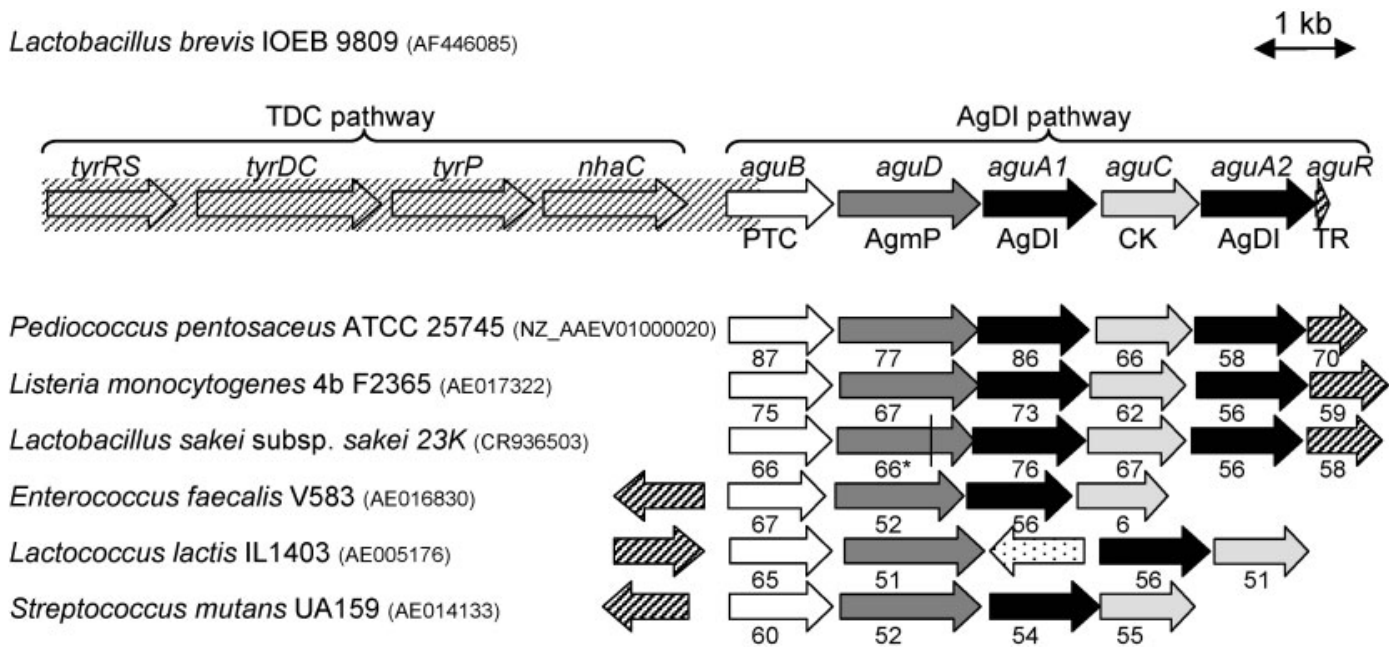

Fig. 1. Genetic organization of the $L b$. brevis IOEB 9809 tyrosine decarboxylase (TDC) and agmatine deiminase (AgDI) gene clusters. Genes (in italics) are designated according to the suggested nomenclature (Naumoff et al., 2004b). The corresponding proteins are: PTC, putrescine transcarbamylase; AgmP, agmatine/putrescine exchanger; AgDI, agmatine deiminase; CK, carbamate kinase; and TR, transcription regulator. The hatched region was sequenced previously (Lucas et al., 2003). Below, a comparison with similar clusters found in other LAB is given. Arrows with the same fill pattern represent corresponding genes. Numbers denote percentages of protein sequence identity relative to the $L b$. brevis genes. In the $L b$. sakei gene cluster, the vertical line indicates the presence of a frameshift. In the Lc. lactis gene cluster, the arrow filled with dots represents a transposase gene. 
the TDC operon was detected that showed high sequence similarity with putrescine transcarbamylases of other LAB, suggesting the presence of the genes for an AgDI pathway. The present study was carried out to examine the possibility that $L b$. brevis contains two catabolic pathways producing two biogenic amines in the same genetic locus. The corresponding DNA region was sequenced and the identified genes and gene products were functionally characterized. In addition, a collection of LAB was screened in order to investigate the presence of similar genes in other LAB.

\section{METHODS}

Bacterial strains. Most of the LAB used in this work were from the collection of the Faculty of Oenology of Bordeaux (IOEB); others were obtained from public or laboratory collections as mentioned in the text or Supplementary Table S1. The strains were grown at $25{ }^{\circ} \mathrm{C}$ in MRS broth (De Man et al., 1960), except for strains of Lc. lactis, which were propagated at $30{ }^{\circ} \mathrm{C}$ in half-strength M17 broth (Terzaghi \& Sandine, 1975) containing $0.5 \%$ glucose and $5 \mu \mathrm{g}$ chloramphenicol $\mathrm{ml}^{-1}$. Escherichia coli strains DH5 $\alpha$ and BL21 (Stratagene) were grown at $37{ }^{\circ} \mathrm{C}$ in LB broth supplemented with kanamycin or ampicillin (each $50 \mu \mathrm{g} \mathrm{ml}^{-1}$ ) when appropriate.

DNA purification, amplification and sequencing. Genomic DNAs were prepared using the Wizard genomic DNA purification kit (Promega). Plasmid purifications were carried out with the Qiaprep miniprep kit (Qiagen). PCRs were routinely performed under standard conditions with appropriate cycling programmes. Repetitive PCRs carried out to analyse a large number of LAB DNAs were performed in the presence of SyBr green dye (IQ SyBr green supermix, Bio-Rad) in the reaction mixture with the following cycling programme: $5 \min 95^{\circ} \mathrm{C}, 35 \times\left[30 \mathrm{~s}\left(95^{\circ} \mathrm{C}\right), 30 \mathrm{~s}\left(55^{\circ} \mathrm{C}\right), 30 \mathrm{~s}\right.$ $\left(72{ }^{\circ} \mathrm{C}\right)$ ] followed by a denaturation step of 65 to $95{ }^{\circ} \mathrm{C}$ allowing determination of the melting temperature of DNA amplicons. The presence of specific amplification products was assessed by analysing the amplification trace records and melting curves.

A DNA template used to sequence the AgDI locus was prepared by PCR using genomic DNA of Lb. brevis IOEB 9809 as template and the primers pFor and pRev (Table 1). pFor matched the published $5^{\prime}$ part of the putrescine transcarbamylase gene of $L b$. brevis IOEB 9809 (Lucas et al., 2003). pRev was designed in a conserved region of the gene of a putative AgDI transcriptional regulator of Pediococcus pentosaceus ATCC 25745 according to the available sequence (accession no. NZ_AAEV01000020). The conserved region was identified by aligning the sequences of $P$. pentosaceus ATCC 25745 and Listeria monocytogenes strain 4b (accession no. AE017322). Sequencing of the PCR product was performed by Millegen (Labege, France). The sequence was deposited in GenBank under the accession no. AF446085.

Determination of biogenic amines. Samples of supernatants of bacterial cultures were filtered through a $0.2 \mu \mathrm{m}$ filter (Millipore), derivatized on a precolumn with $o$-phthalaldehyde and separated by reverse-phase HPLC on a Waters Nova-Pak C18 column according to Pereira-Monteiro \& Bertrand (1994).

Cloning of aguA1, aguA2 and aguD. The genes aguA1, aguA2 and $a g u D$ encoding two putative AgDIs and an agmatine permease (AgmP), respectively, were amplified by PCR with the primer sets AGDI1S + AGDI1E, AGDI2S + AGDI2E and AGMPS + AGMPE (Table 1). The upstream primers introduce an NcoI cleavage site at the start codons and the downstream primers a XhoI or a XbaI cleavage site downstream of the stop codons of each open reading frame. Introduction of the $\mathrm{NcoI}$ sites changed the second amino acid of the aguAl-encoded protein from Lys to Glu, and that of the

Table 1. Primers and plasmids used this study

\begin{tabular}{|c|c|c|}
\hline Designation & Characteristics $^{\star}$ & Source \\
\hline \multicolumn{3}{|l|}{ Primers } \\
\hline pFor & CCGTATTCTGGATATCATTGG & This study \\
\hline pRev & TAGAAAGGTCGCTGTCGATAC & This study \\
\hline AGDI1S & AGGAGTGTGTCACCATGGAAACTTTAGATAGTACC & This study \\
\hline AGDIIE & AGGCTTCCACCGGATCCTCCCGTCCTATTC & This study \\
\hline AGDI2S & CATGGAGTGAGAAACCATGGGATTAGCACAGAC & This study \\
\hline AGDI2E & GATCTGACCCATATTGGATCCCACATAATCAAAG & This study \\
\hline AGMPS & GATAGGACCATGGAAACGGAAAAG & This study \\
\hline AGMPE & CCTTTTTGATCTAGATTAGTCTTTAGTTG & This study \\
\hline AGDIfor & GAACGACTAGCAGCTAGTTAT & This study \\
\hline AGDIrev & CCAATAGCCGATACTACCTTG & This study \\
\hline TDC2 & ACATAGTCAACCATRTTGAA & Coton et al. (2004) \\
\hline TDC5 & CAAATGGAAGAAGAAGTAGG & Coton et al. (2004) \\
\hline TDCAGDIf & GATCCGCTGATGACTGGTGG & This study \\
\hline TDCAGDIr & CGTATCTTCAATCGTTTCGTG & This study \\
\hline \multicolumn{3}{|l|}{ Plasmids } \\
\hline pET30a & $\mathrm{Kan}^{\mathrm{r}}$, expression vector & Novagen \\
\hline pET/aguAl & $\mathrm{Kan}^{\mathrm{r}}$, pET30a derivative carrying aguA1 & This study \\
\hline $\mathrm{pET/aguA2}$ & $\operatorname{Kan}^{\mathrm{r}}$, pET30a derivative carrying aguA2 & This study \\
\hline pNZ8048 & $\mathrm{Cm}^{\mathrm{r}}$, expression vector, nisin-inducible promoter & de Ruyter et al. (1996) \\
\hline pNZAgmP & $\mathrm{Cm}^{\mathrm{r}}$, pNZ8048 derivative carrying $a g u D$ & This study \\
\hline
\end{tabular}

${ }^{*} \mathrm{Kan}^{\mathrm{r}}$, kanamycin resistance; $\mathrm{Cm}^{\mathrm{r}}$, chloramphenicol resistance. 
aguA2-encoded protein from Arg to Gly, while the sequence of AgmP was not affected. The aguA1 and aguA2 PCR products were digested by $N c o I$ and $X h o I$ and inserted into the E. coli expression vector pET30a (Novagen) digested with the same restriction enzymes. The AgmP PCR product was digested with $\mathrm{NcoI}$ and $\mathrm{XbaI}$ and inserted into the corresponding sites of the Lc. lactis expression vector pNZ8048 (Kunji et al., 2003). Sequencing confirmed the presence of the $\operatorname{aguA1}, \operatorname{aguA2}$ and $a g u D$ genes downstream of an in-frame sequence encoding an N-terminal histidine tag in plasmids $\mathrm{pET} /$ aguA1, pET/aguA2 and pNZAgmP, respectively. pET/aguA1 and pET/ aguA2 were transferred into E. coli BL21 and pNZAgmP into Lc. lactis strain NZ9000, which allows expression from a nisin-controlled promoter (de Ruyter et al., 1996).

Expression and purification of aguA1- and aguA2-encoded proteins. E. coli BL21 cells carrying $\mathrm{pET} /$ aguA1 or $\mathrm{pET} /$ aguA2 were grown until the cultures reached $\mathrm{OD}_{600} 0.6$ before adding IPTG to a final concentration of $0.1 \mathrm{mM}$ and allowing the cultures to grow for an additional $3 \mathrm{~h}$. The cells were collected and resuspended in $30 \mathrm{ml}$ buffer A $(50 \mathrm{mM}$ potassium phosphate $\mathrm{pH} 7.5,50 \mathrm{mM} \mathrm{NaCl})$ containing $25 \mathrm{mM}$ imidazole and disrupted in a sonicator (Ultrasonic, MSE Scientific Instruments) with 10 cycles of sonication at $150 \mathrm{~W}$ for $30 \mathrm{~s}$ with intermittent cooling at $4{ }^{\circ} \mathrm{C}$ for $30 \mathrm{~s}$. Cell debris and inclusion bodies were pelleted by centrifugation at $15000 \mathrm{~g}$ for $30 \mathrm{~min}$ and at $4{ }^{\circ} \mathrm{C}$. Purification of the aguAl-encoded protein from the supernatant was performed as follows. The supernatant was loaded onto a $1 \mathrm{ml}$ HiTrap chelating column (Amersham Biosciences), which was previously saturated with a solution of $0.1 \mathrm{M} \mathrm{NiCl}_{2}$. After washing the column with buffer A containing $25 \mathrm{mM}$ imidazole, bound proteins were eluted with a linear gradient of 25 to $250 \mathrm{mM}$ imidazole prepared in the same buffer. Fractions of $0.5 \mathrm{ml}$ were collected and assayed for arginine or AgDI activity. Active fractions were pooled, adjusted to $50 \%(\mathrm{v} / \mathrm{v})$ glycerol, dialysed for $3 \mathrm{~h}$ against 200 vols buffer A containing $50 \%$ glycerol with one buffer change, and stored immediately at $-20{ }^{\circ} \mathrm{C}$. Purification of aguA2encoded protein from inclusion bodies was performed as follows. Inclusion bodies from a 0.51 culture were washed twice in buffer B (20 mM Tris/ $\mathrm{HCl} \mathrm{pH} \mathrm{8.0,100} \mathrm{mM} \mathrm{NaCl)} \mathrm{containing} 1 \%$ Triton X100 and once in buffer B without Triton X-100. The pellet was resuspended in $10 \mathrm{ml}$ buffer B supplemented with $8 \mathrm{M}$ urea and $10 \%$ glycerol and incubated for $1 \mathrm{~h}$ at room temperature while stirring with a magnetic stirrer. The fraction was dialysed for $24 \mathrm{~h}$ against 200 vols buffer B containing $10 \%$ glycerol at $4{ }^{\circ} \mathrm{C}$. Debris was removed by centrifugation for $15 \mathrm{~min}$ at $15000 \mathrm{~g}$ at $4{ }^{\circ} \mathrm{C}$ and the supernatant was filtered on a $0.2 \mu \mathrm{m}$ filter. Glycerol was added up to a final concentration of $50 \%$ and the sample was dialysed for $3 \mathrm{~h}$ at $4{ }^{\circ} \mathrm{C}$ against buffer A containing $50 \%$ glycerol followed by storing at $-20{ }^{\circ} \mathrm{C}$. Protein concentrations were determined using the BCA protein assay kit (Pierce) and BSA as standard. The preparations were analysed by SDS-PAGE followed by Coomassie brilliant blue staining.

Arginine and agmatine deiminase activity assays. Routinely, the assay mixture contained $0.5 \mu \mathrm{M}$ enzyme in $100 \mathrm{mM}$ potassium phosphate $\mathrm{pH} 7.5,50 \mathrm{mM} \mathrm{NaCl}$ and $5 \mathrm{mM}$ of either L-arginine or agmatine sulphate in a reaction volume of $250 \mu \mathrm{l}$. The reaction was initiated by adding the enzyme and stopped at the indicated times by adding $50 \mu \mathrm{l} 50 \%$ trichloroacetic acid. The temperature was $37{ }^{\circ} \mathrm{C}$. Precipitates were removed by centrifugation at $15000 \mathrm{~g}$ for $15 \mathrm{~min}$ at $4{ }^{\circ} \mathrm{C}$. The reaction products, citrulline or carbamoylputrescine, were determined according to the method of Boyde \& Rahmatullah (1980). A $250 \mu \mathrm{l}$ aliquot of supernatant was mixed with $3 \mathrm{ml}$ of a freshly prepared chromogenic solution containing $16.7 \%$ sulphuric acid, $0.05 \%$ butanedione monoxime and $0.01 \%$ thiosemicarbazide. The sample was boiled at $100{ }^{\circ} \mathrm{C}$ for $5 \mathrm{~min}$, cooled to room temperature in the dark and the $A_{530}$ was measured. Citrulline standards were prepared and analysed similarly.
Expression of AgmP and immunoblot analysis. Lc. lactis strain NZ9000 harbouring plasmids pNZagmP or pNZ8048 (see above) was routinely grown to $\mathrm{OD}_{660} 0.6$ followed by induction by adding nisin $\left(0.5 \mathrm{ng} \mathrm{ml}^{-1}\right.$; Sigma-Aldrich). The cells were then allowed to grow for another $1 \mathrm{~h}$, harvested by centrifugation and washed once with $50 \mathrm{mM}$ potassium phosphate buffer $\mathrm{pH}$ 6. The cells were resuspended in $50 \mathrm{mM}$ potassium phosphate $(\mathrm{pH}$ 6) containing $10 \mathrm{mg}$ lysozyme $\mathrm{ml}^{-1}$ and incubated for $10 \mathrm{~min}$ at $50{ }^{\circ} \mathrm{C}$ before being disrupted by sonication. Intact cells and debris were removed by centrifugation for $15 \mathrm{~min}$ at $2910 \mathrm{~g}$, after which membranes were recovered from the supernatant by ultracentrifugation for $30 \mathrm{~min}$ at $288000 \mathrm{~g}$. Membranes were resuspended in the same buffer, and the protein concentration was determined with the DC protein assay kit (BioRad). Membrane proteins were separated by SDS-PAGE and transferred onto a PVDF membrane (Roche) by semidry electroblotting. His-tagged proteins were detected with a primary monoclonal anti-His antibody (Amersham Biosciences) and a secondary antimouse antibody coupled to alkaline phosphatase (Sigma-Aldrich), followed by chemiluminescent detection with CDP-Star (Roche).

Transport assays in whole cells. Lc. lactis NZ9000 cells harbouring plasmids pNZagmP or pNZ8048 were washed once with ice-cold $50 \mathrm{mM}$ potassium phosphate buffer $\mathrm{pH} 6$, and resuspended to an $\mathrm{OD}_{660}$ of 2.0. Following the addition of $0.2 \%$ glucose, $100 \mu \mathrm{l}$ samples were incubated for $5 \mathrm{~min}$ at $30^{\circ} \mathrm{C}$ with constant stirring. At time zero, $\mathrm{L}-\left[\mathrm{U}-{ }^{14} \mathrm{C}\right]$ putrescine was added to a final concentration of $4.2 \mu \mathrm{M}$. Uptake was stopped at the indicated times by the addition of $2 \mathrm{ml}$ icecold $0.1 \mathrm{M} \mathrm{LiCl}$ solution immediately followed by filtering through a $0.45 \mu \mathrm{m}$ pore-size nitrocellulose filter (BA 85; Schleicher \& Schuell). The filter was washed once with $2 \mathrm{ml}$ ice-cold $0.1 \mathrm{M} \mathrm{LiCl}$, submerged in Emulsifier Scintillator Plus scintillation fluid (Packard BioScience) and the retained radioactivity was measured in a Tri-Carb 2000CA liquid scintillation analyser (Packard Instrumentation). The background was estimated by adding the radiolabelled substrate to the cell suspension immediately after the addition of $2 \mathrm{ml}$ ice-cold $\mathrm{LiCl}$, followed by filtering. In the chase experiments, putrescine, agmatine, arginine and ornithine were added after $60 \mathrm{~s}$ at a final concentration of $500 \mu \mathrm{M}$. Experiments were performed at least in triplicate. The results of typical experiments are shown.

Materials. $\left[1,4^{-14} \mathrm{C}\right]$ Putrescine $\left(107 \mathrm{mCi}^{\mathrm{mmol}}{ }^{-1} ; 3.96 \mathrm{GBq}\right.$ $\left.\mathrm{mmol}^{-1}\right)$, L-[U- $\left.{ }^{14} \mathrm{C}\right]$ arginine $\left(292 \mathrm{mCi} \mathrm{mmol}^{-1} ; 10.8 \mathrm{GBq} \mathrm{mmol}^{-1}\right)$ and $\mathrm{L}-\left[1-{ }^{14} \mathrm{C}\right]$ ornithine $\left(256 \mathrm{mCi} \mathrm{mmol}^{-1} ; 9.47 \mathrm{GBq} \mathrm{mmol}^{-1}\right)$ were obtained from Amersham Biosciences. All other compounds were obtained from commercial sources.

\section{RESULTS}

\section{The AgDI gene cluster of $\boldsymbol{L b}$. brevis IOEB 9809}

To determine if the genes of an AgDI pathway were present downstream of the TDC pathway genes in Lb. brevis IOEB 9809, the region was amplified using a forward primer based on the $L b$. brevis IOEB 9809 sequence and a backward primer based on the putative AgDI gene cluster in the $P$. pentosaceus genome. The sequence of the amplified $5.5 \mathrm{~kb}$ DNA fragment revealed a cluster of six genes that was similar to the putative AgDI clusters detected in the genomes of $P$. pentosaceus, Lis. monocytogenes and Lb. sakei (Fig. 1). The putrescine transcarbamylase-encoding $p t c A$ gene is followed by a gene aguD encoding a putative amino acid transporter, AgDI homologue aguAl, the carbamoyl kinase gene $\operatorname{arc} C$ and a second 
AgDI homologue aguA2. The $\operatorname{aguA2}$ gene is followed by $132 \mathrm{bp}$ of the $5^{\prime}$-end of a putative regulator gene aguR. The $a g u R$-encoded protein contains a helix-turn-helix domain involved in DNA binding at the $\mathrm{N}$-terminal extremity and shares similarities with regulators of the RpiR family (Sorensen \& Hove-Jensen, 1996). The gene clusters present in these bacteria differ from the previously characterized AgDI gene clusters in S. mutans and Ent. faecalis. In particular, they contain two genes of putative AgDIs instead of one and have a gene encoding a putative transcription regulator that belongs to the RpiR family rather than the LysR family (Griswold et al., 2006) and that is positioned differently in the cluster. In line with these differences, the translated proteins of Lb. brevis and those of $P$. pentosaceus, Lis. monocytogenes and Lb. sakei shared a high sequence identity, whereas they are more distantly related to the proteins of $S$. mutans and Ent. faecalis.

\section{Biogenic amine production by $L b$. brevis}

The functionality of the predicted AgDI pathway of $L b$. brevis IOEB 9809 was examined by its ability to form putrescine. Lb. brevis IOEB 9809 was grown to the stationary phase of growth in a rich medium supplemented with additional arginine or agmatine. Aliquots of culture supernatants were collected and the presence of a series of biogenic amines was determined by reverse-phase HPLC (Fig. 2). Cells grown under standard conditions produced significant amounts of tyramine (up to $100 \mathrm{mg} \mathrm{l}^{-1}$ ) and minute or undetectable amounts of putrescine, histamine, methylamine, ethylamine, phenylethylamine, isoamylamine and cadaverine. Apparently, the presence of extra arginine in the medium did not result in putrescine production, indicating the lack of a pathway converting arginine into putrescine. Growth in the presence of

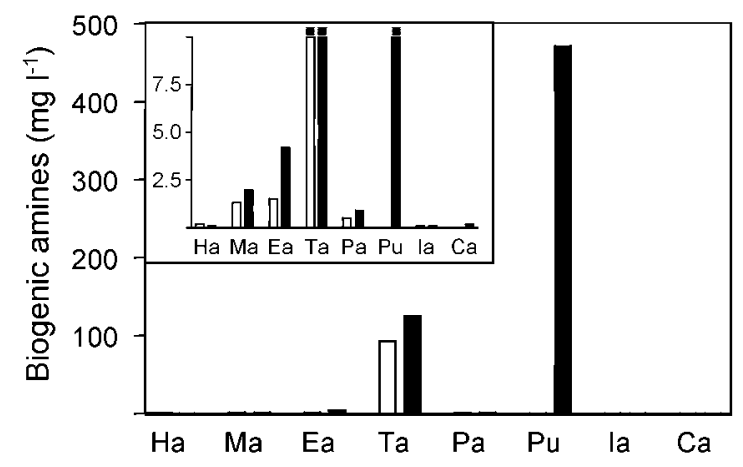

Fig. 2. Biogenic amine production by $L b$. brevis IOEB 9809. $L b$. brevis was grown in MRS broth supplemented with arginine (white bars) or agmatine (black bars). The inset shows the same results on a scale between 0 and $10 \mathrm{mg} \mathrm{I}^{-1}$. Biogenic amines were determined in the supernatant of stationary-phase cultures by reverse-phase HPLC. $\mathrm{Ha}$, histamine; Ma, methylamine; Ea, ethylamine; $\mathrm{Ta}$, tyramine; $\mathrm{Pa}$, phenylethylamine; $\mathrm{Pu}$, putrescine; la, isoamylamine; $\mathrm{Ca}$, cadaverine. agmatine resulted in the same product profile except for the additional production of a high amount of putrescine (almost $500 \mathrm{mg} \mathrm{l}^{-1}$ ), strongly supporting the presence of a functional AgDI pathway in Lb. brevis IOEB 9809. The tyramine production in both growth conditions reflects the activity of the TDC pathway of the bacterium coded by the TDC operon located immediately upstream of the AgDI pathway (Fig. 1).

\section{Functional expression of the Lb. brevis AgDI}

To analyse the roles of the two putative AgDIs of Lb. brevis IOEB 9809, the aguA1 and aguA2 genes were PCR amplified and inserted into the expression vector pET30a downstream of a sequence specifying an N-terminal histidine tag. The resulting vectors pET/aguA1 and pET/ aguA2 encoded recombinant enzymes with calculated molecular masses of 45.3 and $45.6 \mathrm{kDa}$, respectively. They were introduced into E. coli cells for protein expression following IPTG induction. Induction of cells carrying pET/aguAl produced a soluble recombinant enzyme that was purified by $\mathrm{Ni}^{2+}$-NTA affinity chromatography (Fig. 3a). In contrast, induction of cells containing $\mathrm{pET} /$ aguA2 resulted in the production of an insoluble recombinant enzyme detected in inclusion bodies, irrespective of induction conditions. The protein was purified from inclusion bodies using denaturing conditions and tentatively refolded by extensive dialysis against buffer, yielding a soluble protein. SDS-PAGE analysis of the two preparations of recombinant enzymes obtained with $\mathrm{pET} /$ aguA1 and $\mathrm{pET} /$ aguA2 showed in both cases a major band corresponding to a protein of the expected size and a few minor bands of contaminating proteins (Fig. 3a).

Enzymic activities were tested by incubating $0.5 \mu \mathrm{M}$ of each enzyme in reaction mixtures containing $5 \mathrm{mM}$ agmatine or arginine as substrate. The enzyme prepared from $\mathrm{pET} /$ aguAl produced increasing amounts of carbamoylputrescine when incubated in the presence of agmatine (Fig. 3b). Up to $36.3 \%$ of the initial agmatine was converted into carbamoylputrescine in a $60 \mathrm{~min}$ incubation. In contrast, the enzyme proved to be completely unable to form citrulline from arginine (Fig. 3b). The enzyme obtained from $\mathrm{pET} / a g u A 2$ showed no deiminase activity whichever substrate was used. Increasing the enzyme or substrate concentrations or the incubation time did not result in any detectable activity (not shown).

\section{Functional expression of AgmP}

The aguD gene was amplified by PCR using total DNA from $L b$. brevis IOEB 9809 and ligated into the pNZ8048 vector downstream of the nisin-inducible promoter. The resulting plasmid, named pNZAgmP, encodes a recombinant AgmP containing a His-tag at the $\mathrm{N}$ terminus, with a calculated molecular mass of $53 \mathrm{kDa}$. The plasmid was introduced into the expression strain Lc. lactis NZ9000 (de Ruyter et al., 1996; Kunji et al., 2003). 
(a)

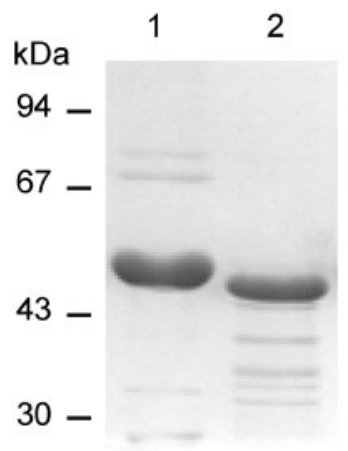

(b)

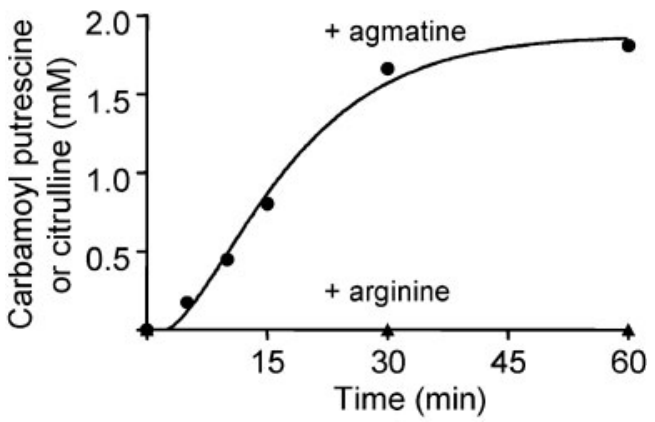

Fig. 3. Analysis of purified aguA1- and aguA2-encoded proteins. (a) Aliquots (5 $\mu \mathrm{g}$ protein) of the purified aguA1 (lane 1) and aguA2 (lane 2) gene products were separated on a $12 \%$ denaturating polyacrylamide gel followed by Coomassie blue staining. Positions of molecular mass markers (Amersham Biosciences) are indicated on the left. (b) The purified aguA1encoded protein $(0.5 \mu \mathrm{M})$ was incubated in the presence of $5 \mathrm{mM}$ arginine $(\mathbf{\Lambda})$ or agmatine $(\mathbf{0})$ and the reaction products, citrulline and carbamoylputrescine, respectively, were measured at the indicated times.

Lc. lactis NZ9000 cells harbouring pNZAgmP or the control vector pNZ8048 were grown in the presence of a 1000-fold range of nisin concentrations, after which cytoplasmic membranes were isolated. Membrane proteins were separated by SDS-PAGE, and His-tagged proteins were detected by immunoblotting using an antibody raised against the His-tag (Fig. 4). A single band corresponding to a protein with an apparent molecular mass of $35 \mathrm{kDa}$ was expressed in the cells containing pNZAgmP and not in the control cells. Integral membrane proteins are known to have a higher mobility on SDS-PAGE, which explains the apparent molecular mass of $35 \mathrm{kDa}$ while the calculated molecular mass is $53 \mathrm{kDa}$. The expression level of AgmP was optimal at a nisin concentration of $0.5 \mathrm{ng} \mathrm{ml}^{-1}$. No expression was observed at a 10-fold lower concentration, while higher concentrations resulted in lower levels of expression.

The ability of AgmP to transport putrescine was demonstrated by measuring uptake of $\left[1,4-{ }^{14} \mathrm{C}\right]$ putrescine in

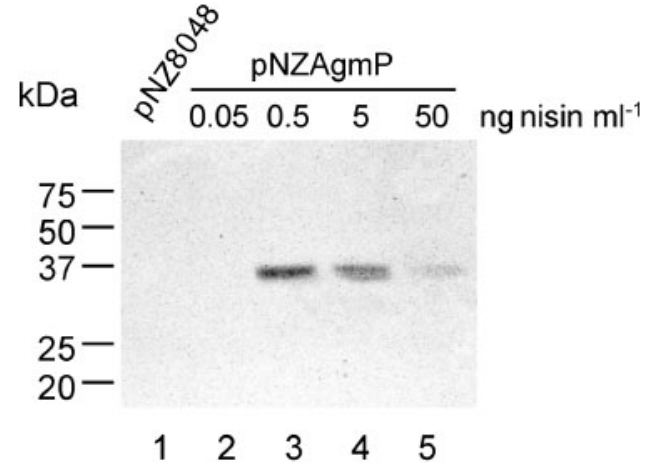

Fig. 4. Expression of AgmP of Lb. brevis in Lc. lactis NZ9000: immunoblot of membrane proteins (15 $\mu \mathrm{g}$ protein per lane) prepared from Lc. lactis NZ9000 cells harbouring vectors pNZ8048 (lane 1) or pNZAgmP (lanes 2-5). Cells harbouring pNZAgmP, encoding AgmP, were grown in the presence of the indicated concentrations of the inducer nisin. Cells harbouring the control plasmid pNZ8048 were induced with $0.5 \mathrm{ng}$ nisin $\mathrm{ml}^{-1}$. Molecular masses of protein standards are indicated on the left.

resting cells of Lc. lactis NZ9000 containing either pNZAgmP or the control vector pNZ8048. The control cells were essentially devoid of uptake activity, indicating the absence of a transporter for putrescine in the Lc. lactis host grown under these conditions (Fig. 5a). In contrast, cells expressing AgmP accumulated putrescine to high levels. At a concentration of $4.2 \mu \mathrm{M}\left[1,4-{ }^{14} \mathrm{C}\right]$ putrescine, the initial rate of uptake was $0.05 \mathrm{nmol} \mathrm{s}^{-1}(\mathrm{mg}$ cell protein $)^{-1}$. The initial rate of uptake and the accumulation level were reduced dramatically in the presence of $10 \mu \mathrm{M}$ of the protonophore CCCP, identifying the electrochemical proton gradient as the driving force of transport (Fig. 5a). Agmatine, which is not commercially available in radiolabelled form, was shown to be recognized by AgmP by its ability to inhibit putrescine uptake. At a concentration of $500 \mu \mathrm{M}$ the inhibition was essentially complete (Fig. 6a).

The AgDI pathway and the arginine deiminase pathways are analogous pathways involving agmatine/putrescine and arginine/ornithine exchange, respectively. Therefore, the ability of AgmP to transport arginine and ornithine was investigated (Fig. 5b, c). The control cells showed significant uptake of both substrates, indicating the presence of endogenous transporters for arginine and ornithine. In cells expressing the $a g u D$ gene, no increased uptake of arginine or ornithine was observed (Fig. 5b, c). In fact, for both substrates, the uptake activities were somewhat lower, suggesting that the driving force for transport is lower in the cells producing the AgmP protein. In line with the apparent inability of AgmP to transport arginine and ornithine, an excess of these two substrates did not inhibit (ornithine) or only marginally inhibited (arginine) the uptake of $\left[1,4-{ }^{14} \mathrm{C}\right]$ putrescine by the cells (Fig. 6a). It follows that AgmP is specific for the substrates agmatine and putrescine. 

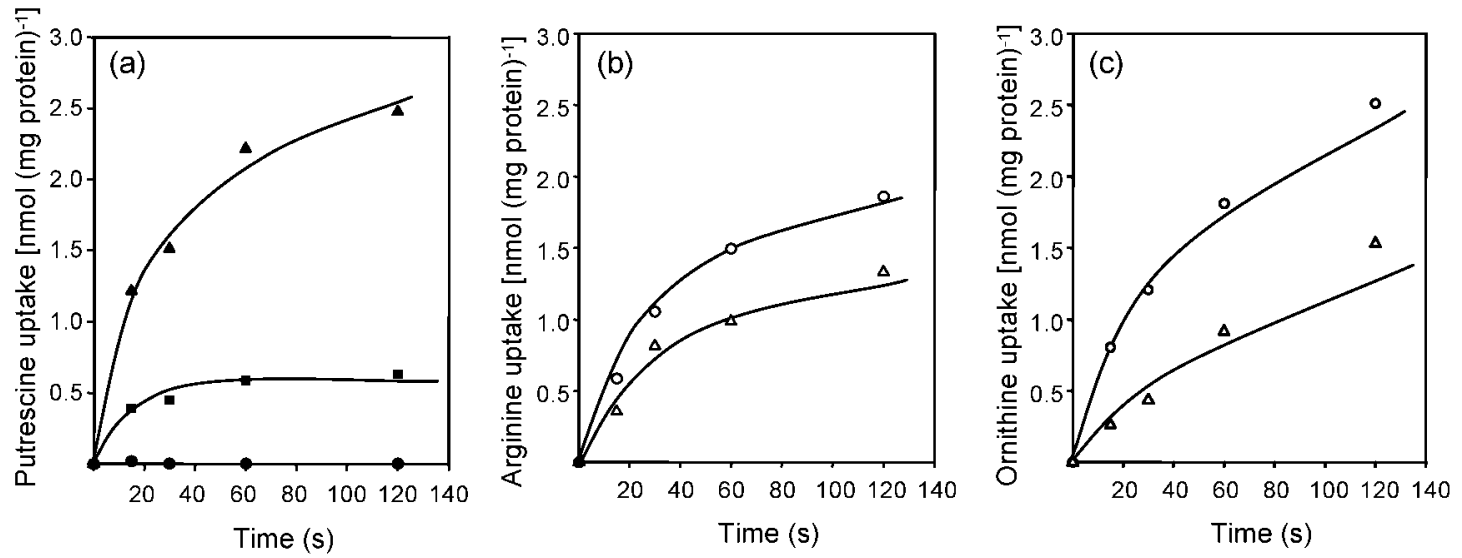

Fig. 5. Uptake of putrescine (a), arginine (b) and ornithine (c) by resting cells of Lc. lactis NZ9000 harbouring pNZ8048 ( $\bigcirc)$ or $\operatorname{pNZAgmP}(\boldsymbol{\Lambda}, \triangle, \boldsymbol{\square})$. (a) Uptake of $4.2 \mu \mathrm{M}\left[1,4-{ }^{14} \mathrm{C}\right]$ putrescine in the absence $(\boldsymbol{\Lambda}, \boldsymbol{\theta})$ or presence $(\boldsymbol{\square})$ of $10 \mu \mathrm{M}$ of the protonophore CCCP. (b) Uptake of $5.5 \mu \mathrm{M} \mathrm{L-}\left[\mathrm{U}-{ }^{14} \mathrm{C}\right]$ arginine. (c) Uptake of $6.3 \mu \mathrm{M} \mathrm{L-}\left[1-{ }^{14} \mathrm{C}\right]$ ornithine. No CCCP was added in (b) or (c).

Inhibition of $\left[1,4-{ }^{14} \mathrm{C}\right]$ putrescine uptake by agmatine (Fig. 6a) demonstrates that the two substrates compete for the binding site on the AgmP protein, but does not show that AgmP transports agmatine. The ability of AgmP to catalyse the translocation of agmatine was demonstrated in a chase experiment (Fig. 6b). Cells expressing AgmP were allowed to take up $\left[1,4-{ }^{14} \mathrm{C}\right]$ putrescine to a steadystate level of accumulation, after which an excess of unlabelled agmatine, putrescine, ornithine or arginine was added to the medium (Fig. 6b). Addition of $500 \mu \mathrm{M}$ agmatine or putrescine resulted in a rapid release of previously accumulated putrescine from the cells. In contrast, addition of the same concentrations of ornithine or arginine did not affect the uptake level of putrescine, confirming the lack of affinity of AgmP for either of them. It follows that AgmP catalyses exchange of agmatine and putrescine.

\section{Screening of LAB for TDC and AgDI gene clusters}

A PCR strategy was used to investigate the presence of genes related to the AgDI and TDC pathways in $197 \mathrm{LAB}$. The strains belonged to 22 different species and were mainly isolated from food products such as wine, beer, apple juice, sugar cane, olive oil, cheese or sauerkraut (see Supplementary Table S1, available with the online version of this paper). Genomic DNAs of the bacteria were purified by a standard procedure, dissolved in water to a final concentration of $50 \mathrm{ng}^{-1} \mathrm{l}^{-1}$ and their quality was controlled by PCR with universal primers specific for bacterial $16 \mathrm{~S}$ rRNA genes. Amplification products of the expected sizes were obtained with all DNA preparations (not shown). Primers AGDIfor and AGDIrev specific for the two genes of the AgDI pathway were designed on the basis of $L b$. brevis IOEB 9809 and P. pentosaceus ATCC
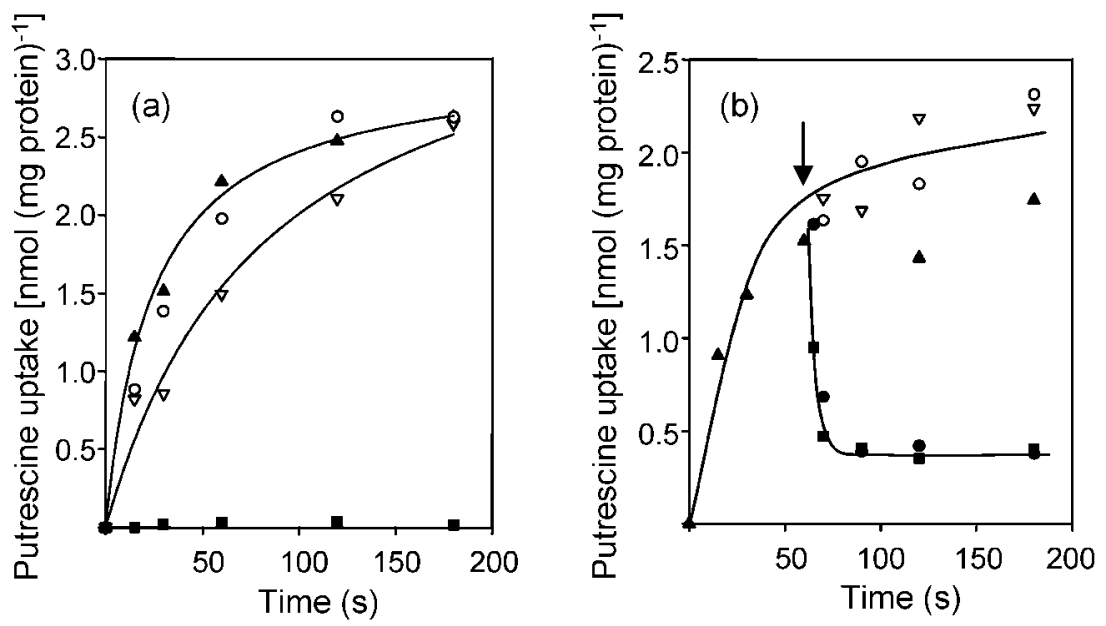

Fig. 6. (a) Inhibition of $\left[1,4-{ }^{14} \mathrm{C}\right]$ putrescine uptake in resting cells of Lc. lactis NZ9000 harbouring pNZAgmP. Cells were allowed to take up $4.2 \mu \mathrm{M}\left[1,4-{ }^{14} \mathrm{C}\right]$ putrescine without any further additions $(\mathbf{\Lambda})$ or in the presence of $500 \mu \mathrm{M}$ of agmatine $(\boldsymbol{\square})$, arginine $(\nabla)$ or ornithine ( $\bigcirc)$. (b) Chase experiments. Cells were allowed to take up $4.2 \mu \mathrm{M}$ $\left[1,4-{ }^{14} \mathrm{C}\right]$ putrescine for $60 \mathrm{~s}(\boldsymbol{\Delta})$. At the arrow $500 \mu \mathrm{M}$ of unlabelled putrescine (O), agmatine $(\mathbf{\square})$, arginine $(\nabla)$ or ornithine $(\bigcirc)$ was added. 
25745 protein sequence alignments. They amplify a $542 \mathrm{bp}$ sequence extending from aguA1 to $\operatorname{arcC}$. The presence of genes of the TDC pathway was investigated by using primers TD2 and TD5, specific for a $1133 \mathrm{bp}$ fragment of the tyrosine decarboxylase gene (Coton et al., 2004). In addition, a third set of primers, TDCAGDIf and TDCAGDIr, was used to examine whether the genes of the two pathways were located in the same genetic locus. The primers amplified a 1177 bp DNA region extending from the $n h a C$ gene of the TDC pathway up to $p t c A$ of the AgDI pathway in Lb. brevis IOEB 9809 (Fig. 1).

Results of PCRs performed with the three primer sets and each of the 197 bacterial DNAs are summarized in Supplementary Table S1. Genes of an AgDI pathway were detected in 36 strains of six different species: Lactobacillus brevis, Lactobacillus casei, Lactobacillus fructivorans, Lactobacillus hilgardii, Lactobacillus sanfranciscensis and Pediococcus parvulus. Most of these strains were isolated from wine (27 strains), the remainder from sugar cane (7 strains) and cheese (1 strain). Not all strains of the six species contained the genes. For example, the species $L b$. brevis includes 14 strains with and 3 strains without $\mathrm{AgDI}$ genes, while only one $P$. parvulus strain was positive and 9 were negative. On the other hand, genes of the AgDI pathway were not detected in 16 species even when numerous strains of these species were tested. For example, the lack of the genes in 30 Oenococcus oeni strains suggests that the AgDI pathway is not a trait of $O$. oeni. Interestingly, genes of the TDC pathway were detected exclusively in strains that also contained genes of the AgDI pathway. Thirty-three of the 36 strains containing genes of the AgDI pathway also contained genes of the TDC pathway. The three strains of $L b$. brevis harbouring only the AgDI pathway genes were all isolated from sugar cane. Most importantly, when both clusters were present, the genes of the two pathways were always detected in the same genetic locus.

\section{DISCUSSION}

\section{Genetic organization of agmatine deiminase pathways in LAB}

Recent identification of the first AgDI and its coding gene has been the starting point for the detection of AgDI genes in LAB (Nakada et al., 2001; Nakada \& Itoh, 2003). Previously, physiological studies had disclosed only two LAB able to convert agmatine into putrescine, Enterococcus faecalis ATCC 11700 (Driessen et al., 1988) and Streptococcus mutans UA159 (Griswold et al., 2004). Now AgDI genes have been detected in species of the genera Lactobacillus, Lactococcus, Enterococcus, Pediococcus, Streptococcus and Listeria.

While all AgDI gene clusters of LAB contain a similar panel of genes encoding AgDI, putrescine transcarbamylase, carbamate kinase and agmatine/putrescine exchanger, two types may be discriminated. S. mutans, Ent. faecalis and Lc. lactis contain clusters with a single AgDI gene and the gene of a transcriptional regulator of the LysR family located upstream and transcribed separately (Griswold et al., 2006). The clusters in Lb. brevis IOEB 9809, Lb. sakei, Lis. monocytogenes and $P$. pentosaceus contain two putative $\mathrm{AgDI}$ genes and a gene encoding a transcriptional regulator of the RpiR family downstream of the cluster and in the same direction. Though no experimental evidence is presented it is likely that the latter actually encodes a transcriptional regulator of the pathway since the gene is located immediately downstream of the second AgDI gene (the first nucleotide of the gene is the last nucleotide of aguA2). Expression and characterization of the two putative AgDIs of $L b$. brevis revealed that one had the typical substrate specificity of an AgDI, whereas the second one showed no deiminase activity. However, the latter was purified under denaturing conditions from inclusion bodies, suggesting that it was possibly not folded properly. Arguing against the latter possibility is a recent study in which critical active-site residues of AgDIs were identified by comparing the crystal structures of arginine deiminases and AgDIs ( $\mathrm{Lu}$ et al., 2006). Aligning the sequences revealed that the essential residues were conserved in the functional $\mathrm{AgDI}$ of $L b$. brevis but not in the second putative AgDI, strongly suggesting that there is only one functional $\mathrm{AgDI}$ in $L b$. brevis. The role of the second enzyme remains to be determined.

\section{Agmatine and arginine deiminase pathways}

The AgDI pathway closely resembles the arginine deiminase pathway. The pathways consist of similar enzymes performing similar reactions and differ only in their substrates. The substrates are also very similar since agmatine is the decarboxylation product of arginine. Therefore, it is surprising to find that the two pathways are genetically and catalytically separated. The AgDI enzyme of Lb. brevis IOEB 9809 converts agmatine to putrescine, but has no activity with arginine whatsoever. Similarly, the exchanger AgmP appears to be highly specific for agmatine/putrescine exchange and lacks affinity for arginine and ornithine. Because of the similarity of the pathways, it could be imagined that the AgDI pathway arose from a duplication of the ADI pathway followed by changes in the specificities of the encoded enzymes. However, recent results suggest that the enzymes of the AgDI pathway evolved independently (Llácer et al., 2006). The authors hypothesized that AgDIs functioned initially in polyamine biosynthesis pathways, and at some point in evolution, they were combined with other enzyme into a novel route for agmatine utilization (Llácer et al., 2006). The strict separation of the specificity of the AgDI and the agmatine/putrescine exchanger supports the hypothesis that the agmatine and arginine pathways evolved independently. Identification of two types of AgDI pathways is in agreement with this idea that AgDI pathways of $\mathrm{LAB}$ result from the association of independent genes that evolved separately. 


\section{Dissemination of AgDI genes in LAB}

In $\mathrm{LAB}$, catabolic pathways of amino acids and derivatives are present in diverse species, but only in a limited number of strains of each species. Therefore, it is generally difficult to isolate positive strains. Recent studies revealed the genes involved in the decarboxylation pathways of glutamate, aspartate, arginine, lysine, histidine and tyrosine in LAB and other bacteria that have to cope with acid environments (Cotter \& Hill, 2003; Fernández \& Zúñiga, 2006, and references therein). All were identified independently in distinct bacteria. Given that the coding genes have high sequence identity it has been proposed that they disseminated in LAB by horizontal gene transfer (Lucas et al., 2005; Fernández \& Zúñiga, 2006). This study shows not only that $L b$. brevis IOEB 9809 contains two catabolic pathways specific for agmatine and tyrosine, but also that the genes involved are located in the same genomic locus. Screening of a collection of LAB revealed that the same situation occurs in many strains belonging to at least six different species of lactobacilli and pediococci. Since the AgDI and TDC pathways function independently, the repeated finding of their genes in the same genomic region of different bacteria suggests that these genes were transferred horizontally together. Moreover, during the preparation of this paper, the genomic sequences of nine LAB were published, including $\mathrm{Lb}$. brevis ATCC 367 (Makarova et al., 2006). Analysis of the genome of this bacterium revealed almost identical AgDI and TDC gene clusters as found in Lb. brevis IOEB 9809 (please note that several genes were erroneously annotated). Interestingly, immediately downstream of the AgDI pathway, the three genes forming the malolactic fermentation operon are found. The well-documented malolactic fermentation pathway (Ansanay et al., 1993; Labarre et al., 1996; Sobczak \& Lolkema, 2005) converts malate to lactate by decarboxylation, thus contributing to acid resistance and metabolic energy production. It appears that $L b$. brevis ATCC 367 contains in the same locus three catabolic pathways: the tyrosine decarboxylation pathway, agmatine deiminase pathway, and the malolactic fermentation pathway. Possibly, this region on the chromosome represents a genomic island involved in acid stress resistance and/or energy generation that is transferred horizontally between different organisms. Further work is in progress to examine this possibility.

\section{ACKNOWLEDGEMENTS}

The authors are grateful to M.-C. Perello for determination of biogenic amine concentrations. This work was supported by the European Commission; contract number QLK1-CT-2002-02388.

\section{REFERENCES}

Alberto, M. R., Arena, M. E. \& Manca de Nadra, M. C. (2007). Putrescine production from agmatine by Lactobacillus hilgardii: effect of phenolic compounds. Food Control 18, 898-903.
Ansanay, V., Dequin, S., Blondin, B. \& Barre, P. (1993). Cloning, sequence and expression of the gene encoding the malolactic enzyme from Lactococcus lactis. FEBS Lett 332, 74-80.

Boyde, T. R. \& Rahmatullah, M. (1980). Optimization of conditions for the colorimetric determination of citrulline, using diacetyl monoxime. Anal Biochem 107, 424-431.

Coton, M., Coton, E., Lucas, P. \& Lonvaud-Funel, A. (2004). Identification of the gene encoding a putative tyrosine decarboxylase of Carnobacterium divergens 508. Development of molecular tools for the detection of tyramine-producing bacteria. Food Microbiol 21, 125130.

Cotter, P. D. \& Hill, C. (2003). Surviving the acid test: responses of Gram-positive bacteria to low pH. Microbiol Mol Biol Rev 67, 429453.

De Man, J. C., Rogosa, M. \& Sharpe, M. E. (1960). A medium for the cultivation of lactobacilli. J Appl Bacteriol 23, 130-135.

de Ruyter, P. G., Kuipers, O. P. \& De Vos, W. M. (1996). Controlled gene expression systems for Lactococcus lactis with the food-grade inducer nisin. Appl Environ Microbiol 62, 3662-3667.

Driessen, A. J., Smid, E. J. \& Konings, W. N. (1988). Transport of diamines by Enterococcus faecalis is mediated by an agmatineputrescine antiporter. J Bacteriol 170, 4522-4527.

Fernández, M. \& Zúñiga, M. (2006). Amino acid catabolic pathways in lactic acid bacteria. Crit Rev Microbiol 32, 155-183.

Griswold, A. R., Chen, Y.-Y. M. \& Burne, R. A. (2004). Analysis of an agmatine deiminase gene cluster in Streptococcus mutans UA159. J Bacteriol 186, 1902-1904.

Griswold, A. R., Chen, Y.-Y. M. \& Burne, R. A. (2006). Regulation and physiological significance of the agmatine deiminase system of Streptococcus mutans UA159. J Bacteriol 188, 834-841.

Kunji, E. R. S., Slotboom, D. J. \& Poolman, B. (2003). Lactococcus lactis as host for overproduction of functional membrane proteins. Biochim Biophys Acta 1610, 97-108.

Labarre, C., Divies, C. \& Guzzo, J. (1996). Genetic organization of the mle locus and identification of a mleR-like gene from Leuconostoc oenos. Appl Environ Microbiol 62, 4493-4498.

Llácer, J. L., Polo, L. M., Tavarez, S., Alarcon, B., Hilario, R. \& Rubio, V. (2006). The gene cluster for agmatine catabolism of Enterococcus faecalis. Studies of recombinant putrescine transcarbamylase and agmatine deiminase and a snapshot of agmatine deiminase catalyzing its reaction. J Bacteriol 189, 1254-1265.

Lolkema, J. S., Poolman, B. \& Konings, W. N. (1996). Secondary transporters and metabolic energy generation in bacteria. In Handbook of Biophysics, pp. 229-260. Edited by W. N. Konings, H. R. Kabac \& J. S. Lolkema. Amsterdam: Elsevier.

Lu, X., Li, L., Wu, R., Feng, X., Li, Z., Yang, H., Wang, C., Guo, H., Galkin, A. \& other authors (2006). Kinetic analysis of Pseudomonas aeruginosa arginine deiminase mutants and alternate substrates provides insight into structural determinants of function. Biochemistry 45, 1162-1172.

Lucas, P. M. \& Lonvaud-Funel, A. (2002). Purification and partial gene sequence of the tyrosine decarboxylase of Lactobacillus brevis IOEB 9809. FEMS Microbiol Lett 211, 85-89.

Lucas, P. M., Landete, J., Coton, M., Coton, E. \& Lonvaud-Funel, A. (2003). The tyrosine decarboxylase operon of Lactobacillus brevis IOEB 9809: characterization and conservation in tyramine-producing bacteria. FEMS Microbiol Lett 229, 65-71.

Lucas, P. M., Wolken, W. A., Claisse, O., Lolkema, J. S. \& LonvaudFunel, A. (2005). Histamine-producing pathway encoded on an unstable plasmid in Lactobacillus hilgardii 0006. Appl Environ Microbiol 71, 1417-1424. 
Makarova, K., Slesarev, A., Wolf, Y., Sorokin, A., Mirkin, B., Koonin, E., Pavlov, A., Pavlova, N., Karamychev, V. \& other authors (2006). Comparative genomics of the lactic acid bacteria. Proc Natl Acad Sci U S A 103, 15611-15616.

Marcobal, A., de las Rivas, B., Moreno-Arribas, M. V. \& Munoz, R. (2006). Evidence for horizontal gene transfer as origin of putrescine production in Oenococcus oeni RM83. Appl Environ Microbiol 72, 7954-7958.

Molenaar, D., Bosscher, J. S., Ten Brink, B., Driessen, A. J. M. \& Konings, W. N. (1993). Generation of a proton motive force by histidine decarboxylation and electrogenic histidine/histamine antiport in Lactobacillus buchneri. J Bacteriol 175, 2864-2870.

Nakada, Y. \& Itoh, Y. (2003). Identification of the putrescine biosynthetic genes in Pseudomonas aeruginosa and characterization of agmatine deiminase and $\mathrm{N}$-carbamoylputrescine amidohydrolase of the arginine decarboxylase pathway. Microbiology 149, 707-714.

Nakada, Y., Jiang, Y., Nishijyo, T., Itoh, Y. \& Lu, C.-D. (2001). Molecular characterization and regulation of the aguBA operon, responsible for agmatine utilisation in Pseudomonas aeruginosa. J Bacteriol 183, 6517-6524.

Naumoff, D. G., Xu, Y., Glansdorff, N. \& Labedan, B. (2004a). Retrieving sequences of enzymes experimentally characterized but erroneously annotated: the case of the putrescine carbamoyltransferase. BMC Genomics 5, 52.

Naumoff, D. G., Xu, Y., Stalton, V., Glansdorff, N. \& Labedan, B. (2004b). The difficulty of annotating genes: the case of putrescine carbamoyltransferase. Microbiology 150, 3908-3911.
Pereira-Monteiro, M. J. \& Bertrand, A. (1994). Validation d'une méthode de dosage. Application à l'analyse des amines biogènes du vin. Bull O I V 765, 916-962.

Silla Santos, M. H. (1996). Biogenic amines: their importance in foods. Int J Food Microbiol 29, 213-231.

Sobczak, I. \& Lolkema, J. S. (2005). The 2-hydroxycarboxylate transporter family. Microbiol Mol Biol Rev 69, 665-695.

Sorensen, K. I. \& Hove-Jensen, B. (1996). Ribose catabolism of Escherichia coli: characterization of the rpiB gene encoding ribose phosphate isomerase B and of the rpiR gene, which is involved in regulation of rpiB expression. J Bacteriol 178, 1003-1011.

Stratton, J. E., Hutkins, R. W. \& Taylor, S. L. (1991). Biogenic amines in cheese and other fermented foods: a review. J Food Prot 54, 460-470.

Tabor, C. W. \& Tabor, H. (1985). Polyamines in microorganisms. Microbiol Rev 49, 81-99.

Ten Brink, B., Damink, C., Joosten, H. M. L. J. \& Huis in't Veld, J. H. J. (1990). Occurrence and formation of biologically active amines in foods. Int J Food Microbiol 11, 73-84.

Terzaghi, B. E. \& Sandine, W. E. (1975). Improved medium for lactic streptococci and their bacteriophages. Appl Microbiol 29, 807-813.

Wolken, W. A., Lucas, P. M., Lonvaud-Funel, A. \& Lolkema, J. S. (2006). The mechanism of the tyrosine transporter TyrP supports a proton motive decarboxylation pathway in Lactobacillus brevis. J Bacteriol 188, 2198-2206.

Edited by: P. W. O'Toole 